\title{
DISSEMINATED DISCOID LUPUS ERYTHEMATOSUS GOING IN FOR SQUAMOUS CELL CARCINOMA: A CASE REPORT
}

Murugan S1, Trishna vaishali M², Adikrishnan S3, Mahalakshmi Veerarabghavan4, Sudha Rangarajan ${ }^{5}$

\section{HOW TO CITE THIS ARTICLE:}

Murugan S, Trishna vaishali M, Adikrishnan S, Mahalakshmi Veerarabghavan, Sudha Rangarajan. "Disseminated Discoid Lupus Erythematosus Going in for Squamous Cell Carcinoma: A Case Report". Journal of Evolution of Medical and Dental Sciences 2015; Vol. 4, Issue 61, July 30; Page: 10735-10737,

DOI: $10.14260 /$ jemds/2015/1549

ABSTRACT: Discoid lupus erythematosus or chronic cutaneous lupus erythematosus begin as erythematous macules, plaques. Plaques surmounted by adherent scales.

KEYWORDS: Coin shaped lesions, Carpet tack sign, follicular plugging.

INTRODUCTION: DLE is a benign disorder of skin which commonly involves the face. The lesions are erythematous scaly plaques of variable size which heal with atrophy, scarring.

Pigmentary changes are seen. We hereby report a case of disseminated discoid lupus erythematous with well differentiated SCC.

CASE REPORT: 52 years old male presented with an asymptomatic lesion over the lower lip, moustache, anterior chest wall, trunk for two years. The lesion over the lower lip progressively increased in size. History of photosensitivity present.

\section{ON EXAMINATION:}

1. Erythematous, depigmented plaque seen over the moustache area measuring $(2 \times 1 \mathrm{~cm})$. Verrucous lesion $(2 \times 2 \mathrm{~cm})$ seen over the lower lip.

2. Erythematous plaque with adherent scaling measuring about $5 \times 4 \mathrm{~cm}$ in size was present over the parasternal region. Atrophy, scarring and pigmentary changes were noted over the lesion and over upper back.

3. Systemic examination was normal.

4. Serological investigations showed -ANA ( positive in 1:80 dilution).

\section{HISTOPATHOLOGY OF LESION FROM CHEST :}

1. Hyperkeratosis in stratum corneum.

2. Concentric rings of keratin (Follicular plugging) in stratum corneum.

3. Squamatisation of stratum basale, Vacuolization of spaces between stratum basale layer seen.

4. Lymphocytic infiltrate, mucin deposits are seen in the dermis

\section{HISTOPATHOLOGY OF LESION FROM LIP:}

Excisional biopsy of the lesion over the lip showed keratin pearls, malignant cells invading the dermis arranged in cords and sheets.

Patient was treated with oral hydroxy chloroquine, topical steroids, sun screens. Patient was advised strict sun protection and asked to come for regular follow up in view of surveillance for evolving malignancies, for early diagnosis and management of malignant, premalignant lesions. 


\section{CASE REPORT}

DISCUSSION: DLE lesions begin as red to purple macules, papules and plaques evolving to form plaques. They rapidly develop into hyperkeratotic lesions. Plaques are covered by adherent scales that extend into the orifices of dilated hair follicles.

When the adherent scales are lifted keratotic spikes are seen below this is called as CARPET TACK SIGN.[1]

Cutaneous lupus erythematosus (DLE) has associations with HLA-B7, B8, CW7, DR2.[2] Disseminated DLE is commonly seen over trunk, limbs. The lesions may resemble papulosquamous type of subacute cutaneous lupus erythematosus.[3]

Disseminated discoid lupus erythematosus can undergo malignant transformation (Squamous cell carcinoma).[4] The risk is higher with disseminated DLE (22\%) than DLE confined to head and neck (1.2\%).[5] Patients must be under surveillance for evolving malignancies.

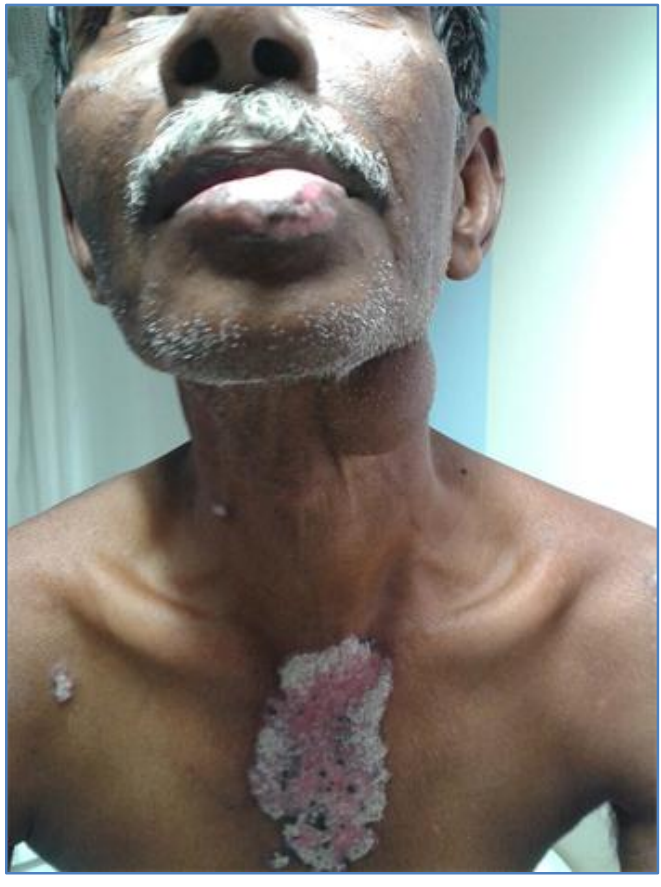

Lesion over the chest

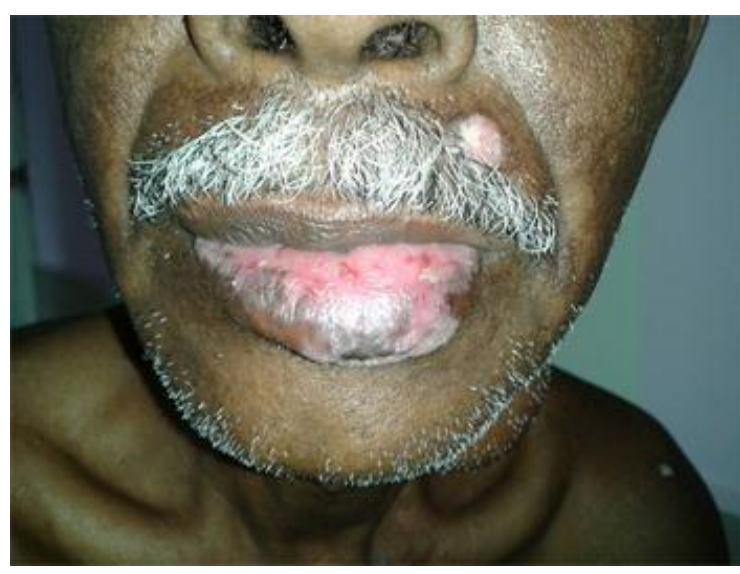

Lesion over lower lip

\section{REFERENCES:}

1. Matsushita S, Ishihara T, Kageshita T, Egawa K, Miyake T, Ono T. Multiple squamous cell carcinomas arising in lesions of discoid lupus erythematosus. J Dermatol 2004; 31: 73-5.

2. Shamsadini S, Shamsadini A. Overlap of squamous cell carcinoma on a chronic discoid lesion of lupus erythematosous on the lower lip of a woman. Internet J Dermatol 2006; 4.

3. Caruso WR, Stewart ML, Nanda VK, Quismorio FP Jr. Squamous cell carcinoma of the skin in black patients with discoid lupus erythematosus. J Rheumatol 1987; 14: 156-9.

4. Dhingra $M$, Bhalla $M$, Thami GP, Mittal P. Metastasizing squamous cell carcinoma arising from chronic discoid lupus erythematosus plaque of recent onset. Indian J Dermatol Venereol Leprol 2011; 77: 626. 


\section{CASE REPORT}

5. Nair VL, Chacko M. Disseminated discoid lupus erythematosus with squamous cell carcinoma. Indian J dermatol Venereol Leprol 1991; 57: 196-7.

\section{AUTHORS:}

1. Murugan S.

2. Trishna vaishali $M$.

3. Adikrishnan S.

4. Mahalakshmi Veerarabghavan

5. Sudha Rangarajan

\section{PARTICULARS OF CONTRIBUTORS:}

1. Professor, Department of Dermatology, Sri Ramachandra Medical College and Research Institute.

2. Junior Resident, Department of Dermatology, Sri Ramachandra Medical College and Research Institute.

3. Associate Professor, Department of Dermatology, Sri Ramachandra Medical College and Research Institute.

FINANCIAL OR OTHER

COMPETING INTERESTS: None
4. Professor, Department of Dermatology, Sri Ramachandra Medical College and Research Institute.

5. Professor, Department of Dermatology, Sri Ramachandra Medical College and Research Institute.

\section{NAME ADDRESS EMAIL ID OF THE CORRESPONDING AUTHOR:}

Dr. Murgan S,

Plot No: 600, New No: 5

Annanagar West Ext,

Chennai-600101.

E-mail: murug1972@gmail.com

Date of Submission: 17/06/2015.

Date of Peer Review: 18/06/2015.

Date of Acceptance: 22/07/2015.

Date of Publishing: 30/07/2015. 